\title{
Russian oil and gas industry as a sphere of international interests and economic cooperation
}

\author{
Lyubov Vasilievna Larchenko ${ }^{1, *}$, Roman Aleksandrovich Kolesnikov ${ }^{2}$, and Liliya Mukhametova ${ }^{3}$ \\ ${ }^{1}$ Herzen State Pedagogical University of Russia St. Petersburg, Russia \\ ${ }^{2}$ Arctic Research Center of the YNAD, Salekhard, Russian Federation \\ ${ }^{3}$ Kazan State Power Engineering University, Kazan, Russian Federation
}

\begin{abstract}
Russia's oil and gas resources fall within the sphere of interests of Western European and a number of Asian countries, mainly China, for which a stable supply of the economy with hydrocarbon raw materials is the most important factor in the development of the economy. At the same time, the vast majority of resources are located in the North and the Arctic zone of Russia. Under conditions of considerable uncertainty in the energy markets, international cooperation between the countries of the Organization of Petroleum Exporting Countries and Russia to regulate the functioning of the industry has deepened. The article shows that in the context of reduced resources, complicating mining conditions, coordination of efforts to conduct joint fundamental research work is necessary. Further successful economic cooperation should be based on the harmonization of the economic interests of all stakeholders.
\end{abstract}

\section{Introduction}

Russia is one of the largest countries in terms of production and supply of hydrocarbons to the world market. At the same time, the vast majority of resources are located in the North and the Arctic zone of the country. Oil and gas resources fall into the sphere of interests of a number of international organizations and countries for which a sustainable supply of the economy with hydrocarbon raw materials is the most important factor for the development of the economy. The Arctic zone of Russia is a unique region rich in hydrocarbon resources. In the face of declining continental hydrocarbon reserves around the world, interest in Arctic resources has increased dramatically, including on the shelf zone. A significant amount of research by scientists and practitioners $[1,2,3,4,5,6]$ is devoted to the development of the resource base of the Arctic, which is caused by the state's installation for the mastering of the Arctic zone of the Russian Federation.

Recently, declining oil prices and sanctions against Russian companies have become decisive in the development of the oil and gas industry in Russia. However, the influence of these factors did not become a significant obstacle in the development of the industry, since during its existence a stable model of the industry has been developed, supported by a huge resource potential [7]. Moreover, in most of the fields in Russia, the low cost of oil production is from 5 to 10 dollars / barrel, and, for example, in Rosneft it amounts to 2.1 dollars / barrel [8].

\section{Research methods}

In order to analyze the current situation, the article used studies of domestic and foreign scientists on the problems of the oil and gas industry of the Russian Federation.

In the process, the following research methods were used: economic and statistical; economic and geographical; comparative analytical; expert assessments; balance. The empirical and information base, in addition to special literary sources and periodicals, was official statistics of the State Statistics Committee of the Russian Federation, official data of the Ministry of Energy of the Russian Federation, materials of major Russian oil and gas companies (Gazprom, Rosneft and others).

\section{Results}

\subsection{Deliveries of Russian hydrocarbons in the context of the economic interests of foreign countries}

In the international aspect, the hydrocarbon resources of the Arctic zone of Russia fall within the sphere of interests of the countries of Western Europe. This is due to the reduction of the own resource base of Western European states, the geographical proximity of the Russian Arctic deposits, and the availability of hydrocarbon transportation facilities from our country. It is expected that the import dependence of the European

\footnotetext{
* Corresponding author: lubalar@mail.ru
} 
Union, on oil, in the next 15-20 years will increase from $74.4 \%$ to $86.1 \%$. At the same time, Europe's desire to avoid monopolization of hydrocarbon supplies from both Russia and OPEC countries is quite natural.

Today, OPEC positions on the world oil market are very strong. The countries that make up this organization account for about $40 \%$ of world production, about $60 \%$ of its world exports, and $30 \%$ of exports of petroleum products. But the basis of their influence on market dynamics is a powerful resource base - $77 \%$ of proven world oil reserves. The average cost of oil production in such large OPEC member countries as Saudi Arabia, Iraq, Iran, Kuwait is less than \$ 2 per barrel, which dramatically increases the competitiveness of Middle Eastern oil to oil from other regions.

Cooperation is developing in the field of energy with the Asian countries, and mainly with China, which has a great interest in the hydrocarbons of Russia, which requires a fast-growing economy of the country.

The Russian Federation actively trades its own hydrocarbons. The EU is considering the possibilities of importing Russian oil and gas in the context of its integrated economic policy in the north of Europe. From this point of view, the Russian North is characterized, on the one hand, as a highly prospective area in its development with a large natural resource potential, and on the other, as problematic in terms of rationality and efficiency of use of both natural and other economic resources, which hampers its socio-economic development and leads to disruption of the ecological balance.

The fundamentally different established models of economic management in Russia and European countries, primarily Scandinavian, predetermined significant differences in the distribution of productive forces, the formation of production and social infrastructure, and the organization of economic activities in the North. The fact is obvious - our model loses to the Scandinavian. This is concentrated in a multiple gap between Norway, Sweden and Finland on the one hand, and the Russian Federation on the other in terms of the indicator "Gross national income per capita". A significant gap in the economic efficiency of production and social welfare is a serious obstacle to international economic integration, the organization of full-fledged regional capital markets, marketable products, and labor.

Over the years, Russian gas supplies to foreign countries and to the domestic market fluctuated sharply. Reasons for a decrease in gas supplies: a decrease in gas purchases by traditional importers, shale gas production in the United States, an increase in the supply of liquefied natural gas, etc. [9].

Prospects for the development of cooperation with European countries are associated primarily with the implementation of the Nord Stream project. Both the Nord Stream project and the Nord Stream 2 project are a logical continuation of the northern gas transmission corridor in the Russian Federation. Moreover, the new trunk gas pipelines in the northern corridor are by far the most modern in the world, and the economic efficiency of supply is much higher.
Great prospects for cooperation with the Asian gas market. Currently, it is the most dynamic, fast-growing and promising market in the world. These are mainly Chinese and Indian markets. In the same way as in Europe, the volume of domestic production in China does not cover the volume of demand growth - the volume of gas imports to the Chinese market in 2017 increased by $22 \%$. Gas import ratio: $50 \%$ - pipeline gas, $50 \%$ - liquefied natural gas (LNG).

With the commissioning of the largest in the world and the most northern natural gas liquefaction plant Yamal LNG with a capacity of 16.5 million tons per year, LNG will be supplied mainly to the countries of the Asia-Pacific region. In July 2018, regular deliveries of LNG to China began. Gas supplies to China are scheduled for the end of December 2019 via the Power of Siberia gas pipeline, the first line of the offshore section of the Turkish Stream project is completed, and the first line of the Nord Stream-2 project is close to completion. However, there are known difficulties. In the exclusive economic zone of Finland, Sweden, and Germany, the pipeline has already been laid, but there is still no permission from Denmark.

The Nord Stream - 2 project involves the construction of two gas pipeline lines with a total capacity of 55 billion cubic meters. meters of gas per year from the coast of Russia through the Baltic Sea to Germany. The cost of construction is estimated at $€ 9.5$ billion, the launch of the pipeline is expected before the end of 2019. For Europe, the construction of Nord Stream-2 and the additional receipt of Russian gas is very important, because, as mentioned earlier, firstly, consumption grows, and, secondly, the rate of production of its own gas decreases. Prices for American liquefied gas, which it actively offers to European countries, are significantly higher than the Russian pipeline.

\subsection{Not sanctions, but joint cooperation in the development of equipment and technologies for deep-sea oil production}

Russia owns the world's largest continental shelf. The development of Arctic deposits occurs in harsh climatic conditions with extreme ice conditions. For the development of hydrocarbon fields, special offshore platforms, underwater communications, and an icebreaking fleet are needed. Implementation of this project is extremely expensive, so the cost of recoverable hydrocarbons, especially at the initial stage, is very high. In addition, the development of offshore hydrocarbon deposits is associated with significant financial, technical, environmental risks. Here it is advisable to study and apply the foreign experience of countries working on the shelf. The development of both the continental part and the shelf zone of the Arctic is hampered by an undeveloped infrastructure, especially transport. Thus, in the Nenets Autonomous District there are no railways, the road network is extremely poorly developed. There is only $0.32 \mathrm{~km}$ of public roads with hard surface per $1000 \mathrm{~km} 2$ of the territory of the Nenets 
Autonomous District, which is 114 times less than in the whole country.

The development of hard-to-reach Arctic fields requires the use of new technologies and equipment, which we do not yet have for this purpose in our country [10]. The sanctions affected the most vulnerable spot in the oil and gas industry - a ban was imposed on the supply of equipment and technologies for work on the deepwater shelf areas (over $152 \mathrm{~m}$ ) [11]. There are very few acceptable technologies for working in the deep-sea areas of the Arctic shelf in the world. Nor are they in Norway, since work there is carried out in less severe conditions than in the Russian zone of the Arctic. Only five US projects in the Beaufort Sea have similar areas for the development of offshore hydrocarbon deposits [12]. These projects have been frozen for a long time [13]. But in 2018, Donald Trump made a bid for offshore mining, signing a new five-year program for licensing the US continental shelf. This means that the shelf is again a priority in the US oil and gas industry, and, apparently, this is why foreign policy barriers have been set up against the shelf projects in Russia. Our countries have the opportunity to jointly develop technologies to work in the harsh conditions of the Arctic, but this is hampered by sanctions. Thus, the imposed sanctions on the supply of equipment and technologies for work in the deep-sea areas of the Arctic makes it impossible for international cooperation to develop the deep-water areas of the Arctic [14,15].

Despite the prohibitions, foreign business seeks cooperation with Russian oil and gas companies. It is simply impossible to exclude Russia from international economic relations, which largely depends on the country's unique raw material resources.

\subsection{Cooperation with oil producing countries and with OPEC countries to regulate the functioning of the industry}

The main goal of OPEC is the coordination of oil production policies and control over world crude oil prices. Russia is not a member of OPEC. There are several economic and political reasons for this, one of which is that Russia values its reputation as a reliable supplier of energy resources, especially for European consumers. Accession to OPEC will deprive our country of the opportunity to conduct a bilateral energy dialogue with Europe, which, undoubtedly, will negatively affect our status. However, recently, especially in the conditions of the global crisis, when oil prices fell below $\$ 50$ a barrel, Russia and OPEC have significantly increased mutual cooperation and coordination of their actions. The fall in oil prices has affected most oil producers. As a result, the economy of the OPEC countries has seriously suffered, since the majority of Middle Eastern oil producing countries now need the price of \$ 70-80 per barrel to balance their budgets. So in Saudi Arabia as a result of a sharp drop in oil revenues, the budget deficit in 2015 amounted to $\$ 100$ billion.

To reduce global oversupply and raise oil prices, an agreement was signed between the OPEC countries and
11 oil-producing countries, including Russia, to reduce oil production. Under the terms of the agreement, production cuts were calculated from the level of October 2016. Since Russia had a production peak in October, therefore, in 2017, production in Russia decreased by only $0.1 \%$, however, Russia fulfilled its transaction obligations by more than $100 \%$. In general, the oil transaction was executed at $128 \%$, although this figure was achieved due to an unprecedented reduction in oil production in Venezuela - by almost a third. Under conditions of considerable uncertainty in the energy markets, international cooperation between OPEC countries and Russia continues. In December 2018, in Vienna, the next Agreement was signed between 24 countries, including OPEC countries and Russia, on the reduction of oil production.

\section{Conclusion}

Summarizing the above, it can be stated that the oil and gas complex of Russia is a sphere of international interests and cooperation not only with various interested countries, but also with international intergovernmental organizations, mainly OPEC. In the context of globalization and high competition in the hydrocarbon raw materials market, when a large number of interests, often mutually exclusive, collide, it is necessary to find compromises in solving major economic problems.

To resolve the above contradictions with the EU, the Russian side will need: to shift the priority of economic goals in favor of long-term ones; abandon the economy of "raw" type in favor of the economy of "innovative"; switch to global methods of measuring economic, social and environmental processes.

Currently, Russia is looking for new gas sales markets, however, despite the interest in Russian energy resources of the countries of the Asia-Pacific region, the current development of the gas market in these countries and the lack of a gas transmission system similar to the European direction, the priority remains with European countries.

Gradually, Russian oil production is approaching a turning point, when there is a serious need to develop new oil fields in more complex geological conditions. This will require the modernization of existing and the introduction of new equipment and technologies. In this connection, there is an urgent need for international scientific cooperation in this field. The interest is mutual and it is to be hoped that economic interests in this sphere will prevail over political ones.

\section{References}

[1] L. Koshcheev, E. Popkov, R. Seit, Operation experience of solar power plants connected to the Russian distributed grid, MATEC Web of Conferences, 07011, 245 (2018).

[2] A.A. Prianikova, A.F. Akhmadieva, A.Y. Khrustaleva, Evaluation of the Waste Processing System in the Concept of Management of the Sustainable Development of the Arctic Zone of 
the Russia, Proceedings of the IEEE International Conference \& Management of Municipal Waste as an Important Factor of Sustainable Urban Development, WASTE, 8554102, 7-9 (2018).

[3] I. Skvortsova, R. Latyshev, M. Oskolkova, Cluster as a form of international cooperation in the development of the Arctic region in the framework of the international innovation system, MATEC Web of Conferences, 04020, 239 (2018).

[4] N.A. Konakhina, Evaluation of Russian Arctic Foreign Trade, Activity IOP Conference Series: Earth and Environmental Science, 180, 1, 012018 (2018).

[5] K. Kikkas, E. Romashkina, Potential Opportunities for the Arctic Transport Space, IOP Conference Series: Earth and Environmental Science, 180, 1, 012016 (2018).

[6] S. Gutman, A. Teslya, Environmental safety as an element of single-industry towns' sustainable development in the Arctic region, IOP Conference Series: Earth and Environmental Science, 180 (1), 012010 (2018).

[7] L.V. Larchenko, R.A. Kolesnikov, Regions of the Russian Arctic Zone: State and Problems at the, International Journal of Engineering \& Technology, 7 (3.14), 369-375 (2018).

[8] I.I. Sechin, Report at the Summit of energy companies of the St. Petersburg, International Economic Forum "Global hydrocarbon markets at a fork: reducing investment in conditions of uncertainty or risk management?" (2016) [Electronic resource]. Available at: https://www.rosneft.ru/upload/site1/attach/0/03/V ystuplenie.pdf (Accessed: 20.04.2019).

[9] L.V. Larchenko, R.A. Kolesnikov, G.P. Tumanova, V.A. Kibenko, Economic Problems of Exploring Hydrocarbons in Russian Northern Provinces in the Context of International Interests, International Journal of Energy Economics and Policy (IJEEP), 6, 3, 529-536 (2016)

[10] A.E. Kontorovich, Global problems of oil and gas and the new paradigm of development of the oil and gas complex of Russia, Science first-hand, 67, 1, 6-17 (2016).

[11] Impact of sanctions on the Russian oil and gas industry, TOPNEFTEGAZ (February 24, 2016) [Electronic resource]. Available at: http://topneftegaz.ru/news/view/110264 (Accessed: 25.04.2019).

[12] A. Konoplyanik, V. Buzovsky, Yu. Popova, N. Troshina, Opportunities and a fork of the Arctic shelf, Oil of Russia, 1, 2, 12-17 (2016).

[13] K. Hill, E. Crooks, R. Milne, K. Adams, Oil companies freeze projects in the Arctic. Vedomosti (2016) [Electronic resource]. Available http://www.vedomosti.ru/business/articles/2015/0 2/06/neftyanie-kompanii-zamorazhivayut-proektiv-arktik (Accessed: 10.04.2019).
[14] A.E. Kontorovich, Global problems of oil and gas and the new paradigm of development of the oil and gas complex of Russia, Science firsthand, 67, 1, 6-17 (2016).

[15] A.M. Mastepanov, The right turn to the east, Oil of Russia, 5-6, 16-22 (2015). 